FINANCIAL SERVICES TODAY 


\title{
FINANCIAL SERVICES TODAY
}

\author{
Daphne Turner \\ Peter Turner \\ Philip Voysey
}

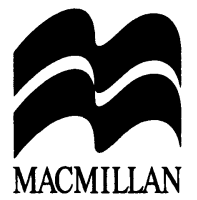


(C) Daphne Turner, Peter Turner and Philip Voysey 1996

All rights reserved. No reproduction, copy or transmission of this publication may be made without written permission.

No paragraph of this publication may be reproduced, copied or transmitted save with written permission or in accordance with the provisions of the Copyright, Designs and Patents Act 1988, or under the terms of any licence permitting limited copying issued by the Copyright Licensing Agency, 90 Tottenham Court Road, London W1P 9HE.

Any person who does any unauthorised act in relation to this publication may be liable to criminal prosecution and civil claims for damages.

First published 1996 by

MACMILLAN PRESS LTD

Houndmills, Basingstoke, Hampshire RG21 6XS

and London

Companies and representatives

throughout the world

ISBN 978-0-333-63689-3

ISBN 978-1-349-13731-2 (eBook)

DOI 10.1007/978-1-349-13731-2

A catalogue record for this book is available from the British Library.

$\begin{array}{rrrrrrrrrr}10 & 9 & 8 & 7 & 6 & 5 & 4 & 3 & 2 & 1 \\ 05 & 04 & 03 & 02 & 01 & 00 & 99 & 98 & 97 & 96\end{array}$

Copy-edited and typeset by Povey-Edmondson Okehampton and Rochdale, England 


\section{Contents}

List of Figures $\quad$ ix

Preface $\quad x$

About the Authors

Acknowledgements xii

\section{BLOCK A FINANCIAL SERVICES - AND BUSINESS NEEDS}

1 Financial services: their growth and importance 3

1.1 What are 'financial services'? 3

1.2 The importance of the financial services sector 9

Check your understanding ... 11

$\begin{array}{ll}\text { Portfolio Assignment } & 12\end{array}$

2 Financial services: the needs 13

2.1 What financial services are needed? 13

2.2 Financial services: who needs which? 16

$\begin{array}{ll}\text { Check your understanding . . . } & 18\end{array}$

Portfolio Assignment 18

3 Finding the capital 19

3.1 What is "capital'? 19

3.2 Capital and the small business 21

Check your understanding . . . 26

Portfolio Assignment 26

4 Corporate finance 27

4.1 The nature of a company 27

4.2 Share capital 28

4.3 Loan capital 32

4.4 Financial services from official bodies 34

4.5 A word on gearing 36

Check your understanding . . . 37

Portfolio Assignment 38 
BLOCK B THE PROVIDERS OF FINANCIAL SERVICES 1 - THE WORLD OF BANKING AND INSURANCE

5 Banking: the basic services 41

5.1 The general picture 41

5.2 Storing money 41

5.3 Collecting money 43

5.4 Transferring money 44

5.5 Lending money 50

5.6 Banks and the creation of credit 51

Check your understanding ... 53

Portfolio Assignment 53

6 More about banking $\quad 54$

6.1 International trade $\quad 54$

6.2 Miscellaneous services $\quad 57$

6.3 Banking: the changing pattern 57

6.4 Other banking institutions 59

Check your understanding . . . 61

Portfolio Assignment 61

7 Managing risks 1 - the business of insurance 63

7.1 The problem of 'risk' 63

7.2 The principles of insurance 63

7.3 The main branches of insurance 66

$\begin{array}{lll}7.4 & \text { Assurance } & 71\end{array}$

7.5 The insurance market $\quad 73$

Check your understanding . . . 75

Portfolio Assignment $\quad 76$

8 Managing risks 2 - risk management policies 77

8.1 The broader aspects of risk $\quad 77$

8.2 The risks involved 78

8.3 The level of risk $\quad 82$

8.4 Towards a risk management policy 83

Check your understanding ... $\quad 85$

Portfolio Assignment $\quad 85$

\section{BLOCK C THE PROVIDERS OF FINANCIAL SERVICES 2 - THE MONEY MARKETS AND OTHER PROVIDERS}

9 The money and capital markets $\quad 89$

9.1 The money market $\quad 89$ 
9.2 The capital market $\quad 92$

9.3 Sources of financial information 95

9.4 Understanding financial information 99

Check your understanding . . . 100

Portfolio Assignment 101

10 Other sources of finance 102

10.1 Leasing and hire-purchase schemes 102

10.2 Factoring 105

10.3 Building societies 106

Check your understanding . . . 111

Portfolio Assignment 111

11 Controlling the providers 112

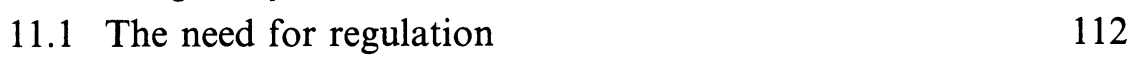

11.2 The new framework 113

$\begin{array}{ll}11.3 \text { Other safeguards } & 118\end{array}$

11.4 The current position $\quad 119$

Check your understanding . . . 120

Portfolio Assignment 120

\section{BLOCK D THE PROVIDERS OF PERSONAL FINANCIAL SERVICES}

12 Personal finance and day-to-day needs 125

12.1 Personal financial services: The changing pattern 125

$\begin{array}{ll}12.2 \text { Meeting present-day needs } & 127\end{array}$

12.3 Banking habits - and change 131

12.4 Travelling abroad 133

Check your understanding ... $\quad 133$

Portfolio Assignment 134

13 Personal finance and credit 135

13.1 Obtaining credit 135

$\begin{array}{ll}\text { 13.2 Credit cards and their use } & 137\end{array}$

13.3 Other credit facilities 140

13.4 Loan and credit card insurance 142

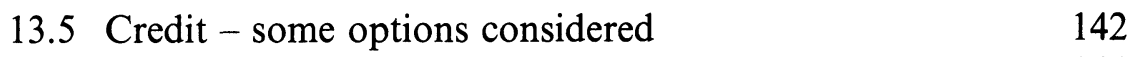

13.6 House purchase 144

Check your understanding . . . 147

Portfolio Assignment 148

14 Personal finance, savings and investment 149

$\begin{array}{ll}14.1 \text { The nature of savings } & 149\end{array}$ 
viii Contents

14.2 The nature of investment 152

14.3 Pension funds 155

14.4 Other aspects of investment 156

Check your understanding . . . 157

Portfolio Assignment 158

$\begin{array}{ll}\text { Index } & 159\end{array}$ 


\section{List of Figures}

1 Growth of financial services sector 9

2 The balance of trade and the balance of payments 11

3 The importance of the financial services sector 11

4 Capital employed 20

5 Capital from own resources 22

6 Partnership 22

7 Loan capital 23

8 Institutional loan capital 24

9 Principal sources of grants and loans for small businesses 25

10 Some of the disadvantages in forming a company 28

11 Raising capital by issuing ordinary shares 30

12 Preference shares 31

13 Raising capital by issuing debentures 33

14 Financial help for larger firms from public bodies 35

15 Functions of commercial banks 42

16 Business bank accounts 43

17 A cheque 45

18 How a bank manager looks at a loan 51

19 The creation of credit 52

20 An international bill of exchange 55

21 The 'staff-less' bank 58

22 The insurance market $\quad 73$

23 Broker service agreements $\quad 84$

24 The money markets 90

25 Hire-purchase: its pros and cons 104

26 Number of building societies in Great Britain, 1850-1992 108

27 Building societies: PLC or not PLC? 110

28 Company legislation and its requirements 114

29 Financial services - the regulatory network 115

30 Functions of the SIB 116

31 Work of the SFA 116

32 Commonsense security hints 129

33 Credit rating agencies' information 136

34 An alternative form of investment - or what is your
teddy worth? 


\section{Preface}

This book covers the Financial Services requirements of the present and planned advanced-level GNVQ Units of the three awarding bodies. It also provides a comprehensive and up-to-date study of the subject for NVQ and business studies students generally.

The GNVQ Units concerned differ slightly in content and structure and therefore the book has been written so that its modules can be studied in any order. A wide range of Activities has been integrated with the text: their completion will provide a major contribution to the information and documentary evidence required by the awarding bodies, and will form a basic resource from which data can be extracted for other set work. Portfolio Assignments, aimed at the requirements of the GNVQ Evidence Indicators, appear at the end of each module.

Financial Services today are provided in a rapidly changing environment. Students should, therefore, seek out and retain relevant press cuttings, magazine articles, notes on radio and television programmes, and any other information which might come their way.

DAPHNE TURNER

Peter Turner

PHILIP VoYseY 


\section{About the authors}

Daphne Turner is by background a mathematician with a special interest in financial administration and managment. She has had extensive teaching experience in schools and colleges at home and overseas, and with the Open University. During the latter years of her full-time working life she held a senior post in educational administration.

Peter Turner has had a wide experience in administration, accounting and teaching both in the UK and overseas. Although now retired, he continues to act as a business studies consultant. He has written a number of books on accounting and finance, and has published several specialist studies dealing with economic problems in developing countries.

His thirty years' experience with a major UK bank has given Philip Voysey a thorough insight into the law and practice of modern banking, an expert understanding of current issues with the financial institutions and a particular understanding of current issues with the financial services sector. He has specialised in insolvency work and has had extensive experience of advising small businesses. 


\section{Acknowledgements}

The authors wish to thank the following for their generous help and assistance: Mrs Judith Johnson, IT Consultant; Mr David Jones of the Securities and Futures Authority; Mr O. W. Roe of the Personal Investment Authority; Ms Heather Smith of the European Information Centre; Ms Katherine Steed of the Securities and Investments Board; Mr Adrian Walsh of the Personal Investment Authority; $\mathrm{Mr}$ Robert Hughes of Redmayne-Bentley. The authors are also grateful to the Midland Bank and to Sotheby's for permission to reproduce the photographs on p. 58 and p. 157 respectively.

Note: The use of the masculine 'he', etc., rather than the more cumbersome 'he/she', etc., is used in this book purely for ease of description. 